\title{
Variable Manganese Rates Influence the Performance of Huanglongbing- affected Citrus Trees in Florida
}

\author{
Samuel Kwakye and Davie M. Kadyampakeni
}

Soil and Water Sciences Department, Citrus Research and Education Center, University of Florida/Institute of Food and Agriculture Science, 700 Experiment Station Road, Lake Alfred, FL 33850

\section{Edzard van Santen}

Statistical Consulting Unit and Agronomy Department, University of Florida, Institute for Food and Agricultural Sciences, Gainesville, FL 32611

\section{Tripti Vashisth}

Horticultural Sciences Department, Citrus Research and Education Center, University of Florida/Institute of Food and Agriculture Science, 700 Experiment Station Road, Lake Alfred, FL 33850

\section{Alan Wright}

Soil and Water Sciences Department, Indian River Research and Education Center, University of Florida/Institute of Food and Agriculture Science, 2199 South Rock Road, Fort Pierce, FL 34945-3138

Additional index words. biomass accumulation, Candidatus Liberibacter asiaticus, CLas, Citrus sinensis, Huanglongbing, HLB, nutrient use efficiency, NUE

\begin{abstract}
Improving nutrient uptake and tree health play an important role in managing Huanglongbing (HLB)-affected citrus trees in Florida. A greenhouse experiment was conducted to evaluate the effect of increasing rates of manganese (Mn) on growth and development of sweet orange [Citrus sinensis (L.) Osbeck] trees at the University of Florida's Institute of Food and Agricultural Sciences (UF/IFAS) Citrus Research and Education Center in Lake Alfred, FL. Half the trees were graft-inoculated with the HLB pathogen and the remainder were used as the HLB-free (non HLB) control trees. Four rates of Mn (0.0 kg·ha ${ }^{-1} \mathrm{Mn}$ (Control), $5.6 \mathrm{~kg} \cdot \mathrm{ha}^{-1} \mathrm{Mn}\left(1 \mathrm{x}\right.$ - standard rate), $11.2 \mathrm{~kg} \cdot \mathrm{ha}^{-1} \mathrm{Mn}(2 \mathrm{x}-$ standard rate), and $22.4 \mathrm{~kg} \cdot \mathrm{ha}^{-1} \mathrm{Mn}(4 \mathrm{x}$ - standard rate) were split applied quarterly to both sets of the trees in a completely randomized design. There were seven single tree replicates for each treatment. Response variables measured were trunk diameter, tree height, leaf $\mathrm{Mn}$ concentration, plus above- and belowground biomass. The accumulated $\mathrm{Mn}$ in leaf tissues significantly increased trunk diameter but did not affect tree height for both HLB-affected and non-HLB trees, the $2 x$ rate had the maximum value for trunk diameter relative to the $4 \mathrm{x}$ rate. This study established a positive correlation between soil available $\mathrm{Mn}$ with $\mathrm{Fe}$ and $\mathrm{Cu}$, but negative correlation with $\mathrm{B}$ and $\mathrm{Zn}$. A strong correlation of $-0.76,-0.69$, and 0.65 was observed between soil $\mathrm{Mn}$ and $\mathrm{B}, \mathrm{Zn}$, and $\mathrm{Cu}$, respectively, as compared with 0.49 with Mn and Fe. Among HLB-affected trees, the $2 x$ rate gave the most belowground dry matter, which was $3 \%$ greater than the control and $5 \%$ greater than $4 x$. Aboveground dry matter had at least $30 \%$ more biomass than belowground matter among all treatments within HLB-affected trees. For small and medium roots, Mn accumulation increased with $M n$ application until 2x rate and decreased thereafter for HLB-affected trees. The results from our study showed an Mn rate of 8.9-11.5 kg·ha Mn, as the optimum Mn level for young 'Valencia' HLB-affected trees in Florida.
\end{abstract}

During the past decade, total citrus production in the United States has declined significantly (Blauer, 2020; USDA-NASS, 2019).

Received for publication 27 Oct. 2021. Accepted for publication 17 Nov. 2021.

Published online 25 January 2022.

D.M.K. is the corresponding author. E-mail: dkadyampakeni@ufl.edu.

This is an open access article distributed under the CC BY-NC-ND license (https://creativecommons. org/licenses/by-nc-nd/4.0/). in Florida around 2005. This disease was first described during the 19th century in China and has now spread to most parts of the world, thus constituting a global threat to the citrus industry (Blauer, 2020; Hall and Gottwald, 2011; USDA-NASS, 2019).

HLB is caused by a phloem-limited bacteria called Candidatus Liberibacter asiaticus (CLas) and spread by an insect-vector Diaphorina citri [Asian citrus psyllid (ACP)] (Gilani et al., 2019; Gottwald et al., 2012; Hijaz et al., 2016; Killiny and Nehela, 2017). The insect-vector pierces through the phloem where it introduces the CLas. Once CLas establishes and develops in the phloem, there is a decline in root mass and fibrous root density as the disease severity increases. This is a defense response by the plant to minimize the spread of the disease (Spreen et al., 2014). This, in turn, leads to a reduction in nutrient and water uptake, and hence, a decrease in citrus yields (Graham et al., 2013; Hamido et al., 2017; Kadyampakeni et al., 2014b, 2014c; Killiny and Nehela, 2017). There is no cure for HLB and management protocols aim to mitigate the detrimental effects through measures such as intensive chemical control of the ACP vector, aggressive removal of HLB-affected trees, severe pruning, planting disease-free nursery stock (Hall and Gottwald, 2011; Rouse et al., 2017), and balanced nutrition (Vashisth and Kadyampakeni, 2020). Balanced nutrition improves citrus tree canopy volume and yield (Morgan et al., 2016; Nwugo et al., 2013; Rouse et al., 2017; Spann and Schumann, 2009; Zambon et al., 2019).

Currently, there are no detailed guidelines for optimal leaf manganese (Mn) concentration in HLB-affected citrus trees in Florida. These guidelines will enable researchers and citrus growers to better understand the role Mn plays in the nutrition of HLB-affected trees. In 2020, the University of Florida's Institute of Food and Agricultural Sciences (UF/IFAS) updated its citrus nutrition guidelines (Morgan and Kadyampakeni, 2020) to guide farm managers and research scientists on balanced citrus nutrition with essential nutrients and their relationship to productivity. However, there is insufficient information on how much more Mn the HLB-affected trees require to maintain balanced levels in the tissues. This study seeks to generate information on how much Mn young HLBaffected trees require, compared with disease-free trees.

Manganese is an essential plant nutrient, taken up in its reduced form $\mathrm{Mn}^{2+}$, and important in many plant metabolic processes, particularly in photosynthesis (Millaleo et al., 2010; Pittman, 2005). Past research has showed that plants absorb Mn by an active transport system in epidermal root cells, where it is transported by the xylem as $\mathrm{Mn}^{2+}$ into the plant system (Gherardi and Rengel, 2004; Marschner, 1995; Millaleo et al., 2010). According to Graham (1979), Mn plays three major roles in the plant system: 1) it assists the movement of electrons in photosynthesis; 2) it affects the reduction of nitrate 
in nitrogen metabolism; and 3) it acts as a precursor for aromatic amino acids and hormones such as in auxins (Clarkson, 1988). Insufficient $\mathrm{Mn}$ triggers deficiency symptoms, which are usually observed when plant growth is extremely depressed. However, the productivity of plants is already affected by the time deficiency symptoms are observed (Schmidt et al., 2016). Zekri and Obreza (2012) reported that Mn deficiency in citrus might significantly reduce yield and fruit quality. Deficiency symptoms are observed in newly emerged leaves because Mn like most micronutrients is partially immobile in the phloem, and as a result, the remobilization of Mn from older to younger leaves is insignificant (Schmidt et al., 2016).

Marschner (1995) mentioned that high levels of Mn could be toxic to cells, and the intensity of the toxicity will depend on the excess Mn concentration in the plant (Lambers et al., 2014; Marschner, 1995). Finding the optimum Mn at which HLB-affected citrus trees may be tolerant is deemed necessary, most importantly, for competition between $\mathrm{Mn}$ and other essential nutrients. This is because antagonism between $\mathrm{Mn}$ and other mineral elements has been reported, where excess $\mathrm{Mn}$ seems to limit the uptake of $\mathrm{Fe}$, $\mathrm{Mo}$, and $\mathrm{Mg}$, which are equally important for plant growth and development (Rietra et al., 2017).

Even though the mechanism by which HLB-affected trees metabolize Mn is not well understood, elevated levels of $\mathrm{Mn}$ have proven to correct deficiency symptoms and resulted in reduced CLas bacterial titers (Zambon et al., 2019). However, it is still not very clear how much Mn should be applied to young, HLB-affected trees to maintain an optimal tissue concentration. Although some researchers reported that $\mathrm{Mn}$ rates in the order of 3-4x current recommendations are optimal for bearing orange trees (Morgan et al., 2016; Zambon

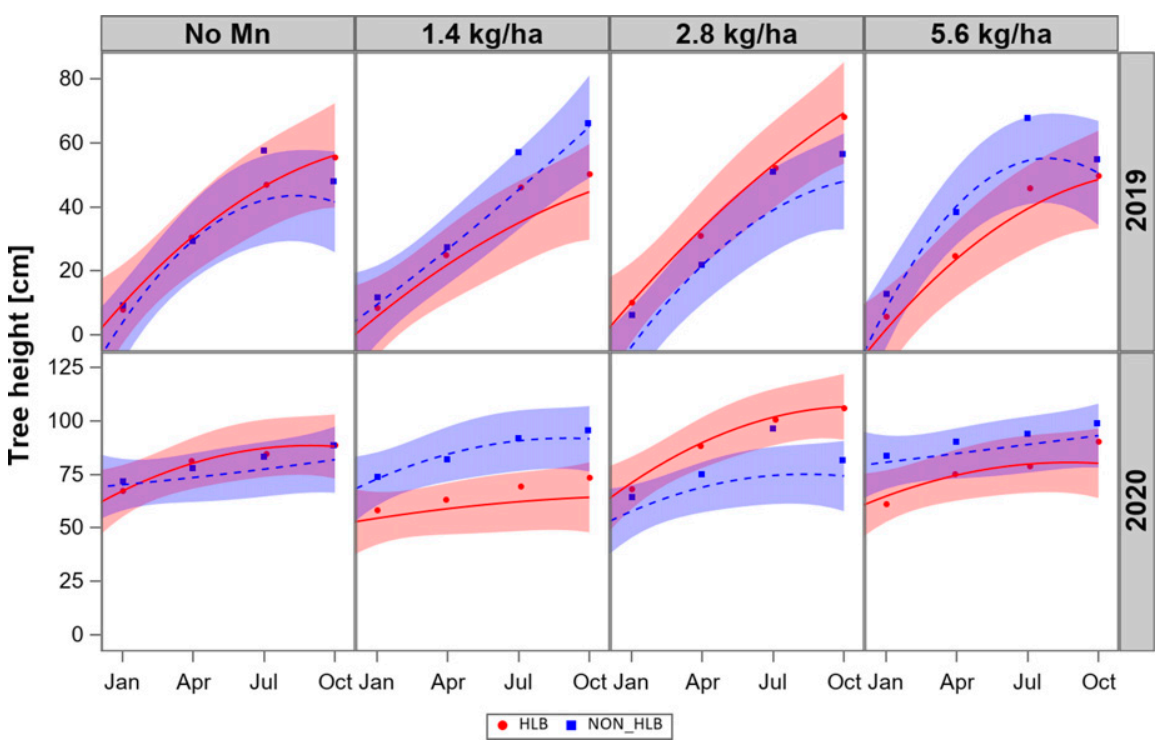

Fig. 1. Tree height (centimeters) as affected by Mn treatment application on Huanglongbing (HLB)and non-HLB-affected 2-year-old 'Valencia' (Citrus sinensis) trees across multiple sampling times (3, 6, 9, and 12 months) in 2019 and 2020. For each year, Mn rate was applied quarterly. Response variable was fitted with a second-order polynomial regression of time nested within $\mathrm{Mn}$ rate $\times$ HLB $\times$ year combinations. Data presented are the least square means (solid and dash lines) and bands represents lower and upper confident intervals.

et al., 2019), this may not be appropriate for young non-bearing orange trees. Therefore, the objective of this study was to evaluate the effect of increasing Mn rates on citrus tree height, trunk diameter, leaf $\mathrm{Mn}$ levels, and biomass accumulation of 2-yearold HLB-affected and HLB-free 'Valencia' [Citrus sinensis (L.) Osbeck] trees under greenhouse conditions in Florida.

\section{Materials and Methods}

Site description and trial establishment. This study was conducted for 2 years in the greenhouse at the UF/IFAS Citrus Research and Education Center (CREC) (lat. $28^{\circ} 5^{\prime} 37^{\prime \prime} \mathrm{N}$, long. $\left.81^{\circ} 43^{\prime} 30^{\prime \prime} \mathrm{W}\right)$ to evaluate the effect of increasing Mn rates on 2-year-old 'Valencia' trees on Kuharske citrange rootstock [Citrus sinensis (L.) Osbeck $\times$ Poncirus trifoliata]. Each tree was transferred to $8.7-\mathrm{L}$ pot; $50 \%$ of the trees were graft-inoculated with the HLBcausal pathogen CLas and remaining trees used as HLB-free controls. The trees were left for 3 months to establish CLas infection.

Initial measurements of tree height and trunk diameter were recorded before a treatment was applied. At the same time, leaves were sampled and analyzed for leaf $\mathrm{Mn}$ and other essential nutrients. Treatments were then applied once confirmed positive for CLas inoculation using a quantitative polymerase chain

Table 1. Least squares Mn rate $\times$ HLB $\times$ year means for tree height, trunk diameter, and leaf Mn concentration as a function of soil Mn application on HLB and non-HLB 2-year-old 'Valencia' [Citrus sinensis (L.) Osbeck] in 2019 and 2020. Response variables were fitted with a second-order polynomial regression of time nested within Mn rate $\times$ HLB $\times$ year combinations. Means presented in this table are for 12 mo. After the initial application in each year. Total sample $(\mathrm{N}=28)$ for each category. Means within an HLB status $\times$ year $\times$ response combination followed by the same letter are not significantly different at $\alpha=0.05$.

\begin{tabular}{|c|c|c|c|c|c|c|}
\hline Mn rate $\left(\mathrm{kg} \cdot \mathrm{ha}^{-1} \mathrm{Mn}\right)$ & \multicolumn{3}{|c|}{2019} & \multicolumn{3}{|c|}{2020} \\
\hline & \multicolumn{6}{|c|}{ HLB } \\
\hline 1.4 & $45 \pm 7.46 \mathrm{~b}$ & $0.61 \pm 0.05 \mathrm{a}$ & $160.4 \pm 86.19 \mathrm{c}$ & $64.3 \pm 8.20 \mathrm{c}$ & $0.78 \pm 0.05 \mathrm{~b}$ & $399.7 \pm 90.47 \mathrm{C}$ \\
\hline 2.8 & $69 \pm 7.95 \mathrm{a}$ & $0.69 \pm 0.05 \mathrm{a}$ & $527.6 \pm 82.01 \mathrm{~b}$ & $106.6 \pm 7.67 \mathrm{a}$ & $0.96 \pm 0.05 \mathrm{a}$ & $1100.7 \pm 88.90 \mathrm{~B}$ \\
\hline 5.6 & $49 \pm 7.63 \mathrm{ab}$ & $0.60 \pm 0.05 \mathrm{a}$ & $1132.6 \pm 82.02 \mathrm{a}$ & $80.2 \pm 8.13 \mathrm{bc}$ & $0.75 \pm 0.05 \mathrm{~b}$ & $2429.3 \pm 90.92 \mathrm{~A}$ \\
\hline 1.4 & $65 \pm 8.03 \mathrm{a}$ & $0.61 \pm 0.05 \mathrm{ab}$ & $186.9 \pm 86.09 \mathrm{c}$ & $91.6 \pm 7.64 \mathrm{a}$ & $0.99 \pm 0.05 \mathrm{a}$ & $548.3 \pm 80.39 \mathrm{C}$ \\
\hline 2.8 & $48 \pm 7.49 \mathrm{ab}$ & $0.71 \pm 0.06 \mathrm{a}$ & $590.2 \pm 89.29 \mathrm{~b}$ & $74.2 \pm 8.22 \mathrm{a}$ & $1.03 \pm 0.05 \mathrm{a}$ & $1388.9 \pm 80.93 b$ \\
\hline \multirow[t]{2}{*}{5.6} & $51 \pm 8.17 \mathrm{ab}$ & $0.50 \pm 0.06 \mathrm{~b}$ & $1823.6 \pm 91.20 \mathrm{a}$ & $93.1 \pm 7.44 \mathrm{a}$ & $0.72 \pm 0.05 \mathrm{~b}$ & $3073.1 \pm 87.64 \mathrm{~A}$ \\
\hline & \multicolumn{6}{|c|}{ Sources of variation } \\
\hline $\mathrm{HLB} \times \mathrm{Mn} \times$ Year & $<0.001$ & $<0.001$ & $<0.001$ & $<0.001$ & $<0.001$ & $<0.001$ \\
\hline Time $($ HLB $\times \mathrm{Mn} \times$ Year $)$ & $<0.001$ & $<0.001$ & $<0.001$ & $<0.001$ & $<0.001$ & $<0.001$ \\
\hline
\end{tabular}

HLB $=$ Huanglongbing 
reaction analysis (qPCR - Applied Biosystems 7500 Fast Real-Time PCR System, Foster City, CA). Water was supplied to each pot by drip irrigation with pressure-compensating drip emitters at a rate of $2 \mathrm{~L} \cdot \mathrm{h}^{-1}$ (MaxiJet, Dundee, FL). Trees were provided with all essential nutrients according to the UF/IFAS nutritional guide for citrus production (Morgan and Kadyampakeni, 2020).

Soil type and characterization. The soil used for this experiment was a Candler fine sand consisting of about $96 \%$ fine sand and classified as hyperthermic, uncoated, Typic Quartzipsamment with less than 2\% organic matter. This soil is typically found in central Florida ridge orange groves and is excessively well drained. The A and E horizons were collected and sieved with a $2-\mathrm{mm}$ mesh to get rid of unwanted materials and obtain a uniform growth medium. A composite soil was then oven-dried at $100^{\circ} \mathrm{C}$, and then tested for Mehlich-3 extractable nutrients. All deficient elements, except $\mathrm{Mn}$, were added as per recommendation. While this soil is excessively drained and very permeable in its natural state, it tends to compact and drain poorly when placed in plastic pots and used under greenhouse conditions. Therefore, perlite was added to the soil at a rate of four parts of soil to one part of perlite by volume to correct this problem.

Treatment application. In the greenhouse, trees were separated into two groups based on HLB status, viz. HLB and non-HLB trees. In each group, there were 28 experimental units with seven replicate pots for each of four $\mathrm{Mn}$ rates, applied as $\mathrm{Mn}$ (II) sulfate monohydrate $\left(\mathrm{MnSO}_{4} \cdot \mathrm{H}_{2} \mathrm{O}, 31.8 \% \mathrm{Mn}\right)$, viz. 1) Control: $0.00 \mathrm{~kg} \cdot \mathrm{ha}^{-1} \mathrm{Mn}$; 2) $5.6 \mathrm{~kg} \cdot \mathrm{ha}^{-1}$ $\mathrm{Mn}$, which is the standard UF/IFAS recommended rate $(1 \mathrm{x})$; 3) $11.2 \mathrm{~kg} \cdot \mathrm{ha}^{-1} \mathrm{Mn}=2 \mathrm{x}$; and 4) $22.4 \mathrm{~kg} \cdot \mathrm{ha}^{-1} \mathrm{Mn}=4 \mathrm{x}$. All treatments were hand-applied and -mixed into to the upper 5-cm of soil, four times a year. As indicated earlier, all other essential nutrients were applied uniformly to all experimental units (pots) 1 week before the Mn rates, using similar application method.

Tree height and trunk diameter. Initial tree height and trunk diameter were measured for each experimental unit before a treatment was applied. Subsequently, a measuring pole height stick (model 807396; SOKKIA Corporation, Olathe, KS) and a digital caliper were used to measure tree height and diameter respectively, every three months at the same location on the trunk. The digital caliper recorded the trunk diameter in the North-South (NS) and East-West (EW) directions of the tree. In terms of tree height and trunk diameter, relative growth was estimated subtracting the initial before treatment application measurement from subsequent measurements.

Leaf and soil Mn concentration. Leaf samples were collected from each experimental unit before a treatment was applied and every 3 months afterward. Ten fully expanded 4- to 6-month-old leaves were sampled; immature, abnormal-appearing, and dead leaves were avoided during leaf collection. Leaves were handwashed with deionized water

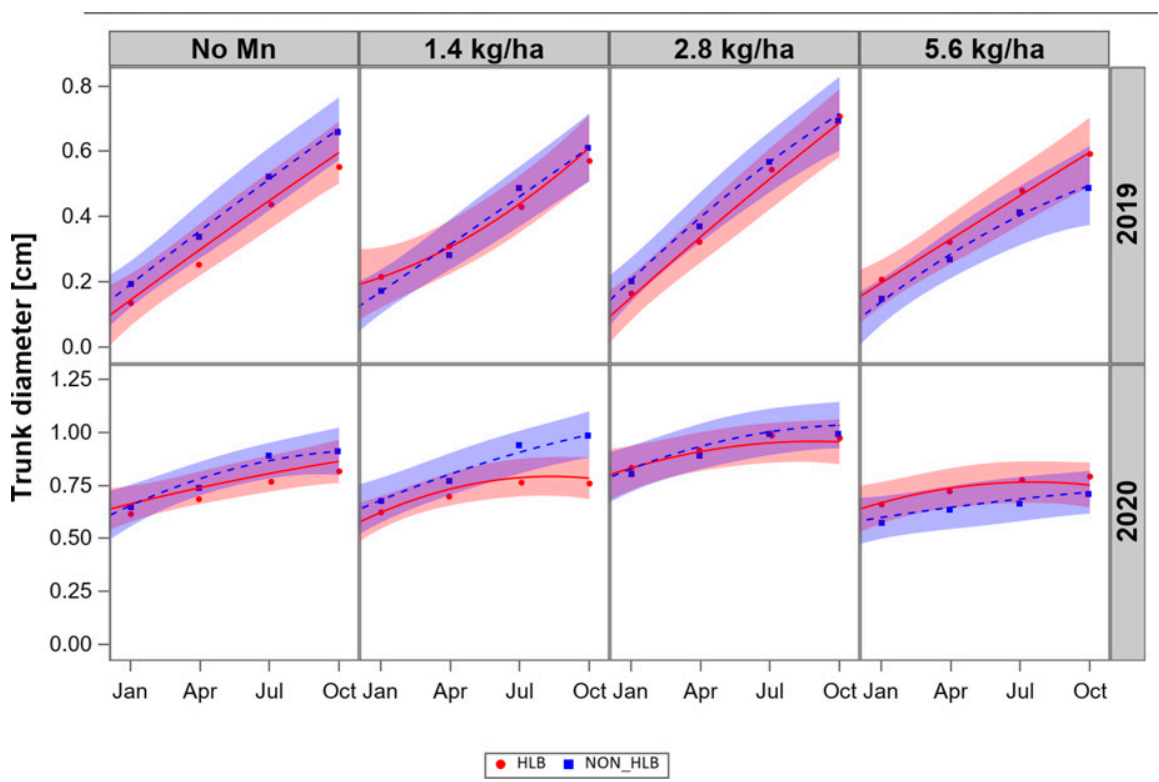

Fig. 2. Effect of Mn treatments on trunk diameter (centimeters) across multiple sampling times (3, 6, 9, and 12 months) under four Mn application rates in 2019 and 2020. For each year, Mn rate was applied quarterly. Response variable was fitted with a second-order polynomial regression of time nested within Mn rate $\times$ HLB $\times$ year combinations on Huanglongbing (HLB)-affected and nonHLB-affected 2-year-old 'Valencia' (Citrus sinensis) trees. Data presented are the least square means (solid and dash lines) and bands represents lower and upper confident intervals. immediately after sampling to remove surface contamination. Leaves were then put into paper bags and dried in a ventilated oven at $65^{\circ} \mathrm{C}$ for at least $72 \mathrm{~h}$ (Morgan and Kadyampakeni, 2020). After drying, leaves were ground with Thomas Type Lab Wiley Mill (PSAW-180, Swedesboro, NJ) equipped with a 20-mesh sieve. Leaf tissue samples were then sent to Waters Agricultural Laboratories, Inc. (Camilla, GA) to determine elemental concentrations of selected nutrients, including $\mathrm{Mn}$.
Soil samples were collected to a depth of 15 $\mathrm{cm}$ at the beginning of the study and the end of the two years. Samples were dried in a ventilated oven at $100^{\circ} \mathrm{C}$ for at least $24 \mathrm{~h}$. The soil samples were then analyzed using inductively coupled plasma atomic emission spectroscopy (ICP-AES), for Mehlich-3 extractable Mn and other selected nutrients. Soil Mn data were correlated with soil $\mathrm{B}, \mathrm{Zn}, \mathrm{Fe}$, and $\mathrm{Cu}$ to observe the relationship between them. This relationship enabled us to explain what

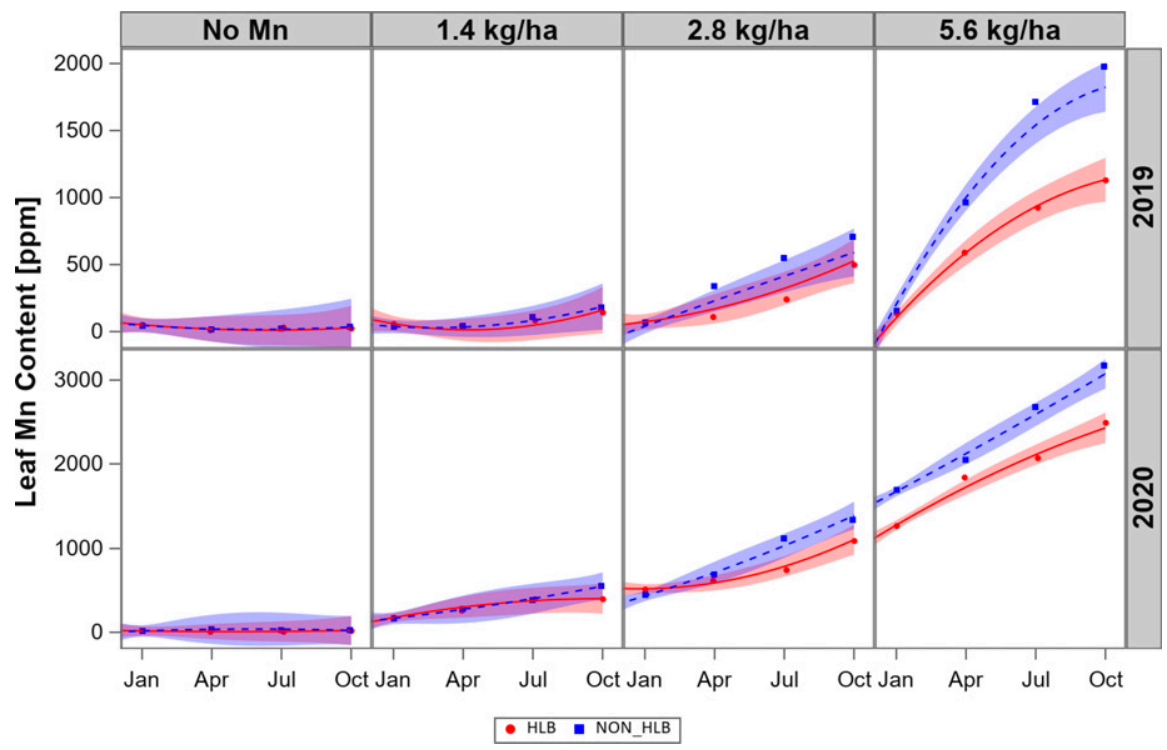

Fig. 3. Leaf manganese (Mn) concentrations across multiple sampling times (3, 6, 9, and 12 months) as a function of Mn application rates on Huanglongbing (HLB)-affected and non-HLB-affected 2year-old 'Valencia' (Citrus sinensis) trees in 2019 and 2020. For each year, Mn rate was applied quarterly. Response variable was fitted with a second-order polynomial regression of time nested within Mn rate $\times$ HLB $\times$ year combinations. Data presented are the least square means (solid and dash lines) and bands represents lower and upper confident intervals. 
happens to the above-mentioned micronutrients upon increasing soil $\mathrm{Mn}$.

CLas DNA concentration in leaf tissue. Symptomatic fully expanded leaves with attached petiole were collected in Spring 2019 and 2020. The midrib was separated from the leaf, cut into 5-mm long pieces and immediately stored in 2-mL centrifuge tubes at $-20{ }^{\circ} \mathrm{C}$ until analysis. Samples were analyzed by qPCR (7500 Fast Real-Time PCR System; Applied Biosystems, Foster City, $\mathrm{CA})$ to retrieve the cycle threshold $(\mathrm{Ct}) \mathrm{val}-$ ues. A PCR in real time was used to quantify the amount of target DNA present in the sample (Ananthakrishnan et al., 2013). For the primers and probe, a working stock solution of $100 \mu \mathrm{L}$ of $20 \mu \mathrm{m}$ was made by diluting a $100 \mu \mathrm{m}$ solution, which is usually purchased from a manufacturer. A method described by Ananthakrishnan et al. (2013) was then followed to set up and run the plate to obtain results.

Tree dry matter and Mn accumulation. At the end of the second year, three trees out of seven were randomly selected from each treatment and separated into roots, trunk, branches, and leaves. Roots were further subdivided into roots with diameter less than 1 $\mathrm{mm}$ (fine roots), roots between 1 and $3 \mathrm{~mm}$ of diameter (medium roots), and roots with diameter greater than $3 \mathrm{~mm}$ (large roots). Branches were divided into twigs (diameter $<3 \mathrm{~mm}$ ) and true branches (diameter $>3$ $\mathrm{mm}$ ). Fresh and dry mass was determined and followed by nutrient analysis. Fresh plant material was dried to constant weight in a ventilated oven at $65^{\circ} \mathrm{C}$; this took between $72 \mathrm{~h}$ for leaves and $12 \mathrm{~d}$ for trunks. The nutrient analysis was used to calculate the amount of $\mathrm{Mn}(\mathrm{mg})$ that accumulated in each plant part. Accumulation of $\mathrm{Mn}$ in each tissue part was calculated by multiplying the dry weight of the tree part by its mean Mn concentration. The information generated from this calculation was used in a regression analysis of dry weight $\mathrm{Mn}$ accumulation as a function of $\mathrm{Mn}$ application rate.

Data analysis. We used linear mixed model methodology as implemented in SAS PROC GLIMMIX (SAS/STAT 15.1; SAS Institute, Cary, NC, 2018) to analyze the response data. Response variables measured every 3 months (tree height, trunk diam, leaf Mn) HLB status, Mn rate, year, and time (in 3-month intervals) were modeled through a second order polynomial, where time was nested within HLB $\times$ Mn rate $\times$ Year combinations, viz.

Response $=$ HLB $\mid \mathrm{Mn}$ rate $\mid$ Year + Time $($ HLB $\times$ Mn rate $\times$ Year $)+$ Time $\times$ Time $($ HLB $\times$ Mn rate $\times$ Year), where the vertical bars indicate a complete factorial combination for the three factors. An unstructured covariance model (UN) was chosen as a best fit to model the repeated nature of this databased on Akaike's Information Criterion corrected for small sample size (AICC).

The linear model for the analysis for response variables measured at the end of the experiment (Biomass and Mn weight estimation, tree dry matter, and dry weight
Table 2. Pearson's correlation coefficient ( $r$ ) comparing soil $\mathrm{Mn}$ with $\mathrm{B}, \mathrm{Zn}, \mathrm{Fe}$, and $\mathrm{Cu}$ as a function of soil Mn application for Huanglongbing (HLB) and non-HLB-affected 2-year-old 'Valencia' [Citrus sinensis (L.) Osbeck] trees. Total sample $(\mathrm{N}=12)$ for each category.

\begin{tabular}{lrrrr} 
& \multicolumn{2}{c}{ HLB } & \multicolumn{2}{c}{ Non HLB } \\
\cline { 2 - 4 } Element & $r$ & $P$ value & $r$ & $P$ value \\
\hline Boron & -0.76 & 0.0045 & -0.58 & 0.0498 \\
Zinc & -0.69 & 0.0127 & -0.52 & 0.0837 \\
Iron & 0.49 & 0.1041 & -0.02 & 0.9490 \\
Copper & 0.65 & 0.0215 & 0.33 & 0.3008 \\
\hline
\end{tabular}

and Mn accumulation) was based on a complete factorial combination of treatment factors HLB and Mn rate. Visual inspection of residuals (Kozak and Piepho, 2018) indicated no violations of the underlying assumptions.

\section{Results}

Tree height and trunk diameter. Tree height over time increased, irrespective of the $\mathrm{Mn}$ rate (Fig. 1). At the end of year one (2019), HLB-affected trees that had received the $2 \mathrm{x}$ rate increased height by $55 \%$ compared with trees that received the $1 \mathrm{x}$ rate; the latter was not significantly different from the control or the $4 \mathrm{x}$ rate (Table 1). This trend was similarly observed after the second year, where the trees receiving the $2 \mathrm{x}$ rate were $66 \%$ taller than trees receiving the standard rate. In contrast, there were few or no differences in tree height for non-HLB trees. Trunk diameter also increased over time, irrespective of HLB status or Mn rate, with larger increases in year one compared with year 2 (Fig. 2); no significant differences were observed for HLB-affected trees across all $\mathrm{Mn}$ rates at the end of year one (Table 1). However, HLB-affected trees that received the $2 \mathrm{x}$ rate increased trunk diameter by $23 \%$ when compared with trees that received $1 \mathrm{x}$ and $4 \mathrm{x}$. Non-HLB trees generally followed a similar growth trend as HLB-affected trees (Figs. 1 and 2).
Leaf and soil Mn concentration. Leaf Mn concentration increased over time in all treatments, except the untreated control; nonHLB trees had higher tissue Mn concentrations than HLB trees, especially at the highest rate (Fig. 3). As expected, Mn rate affected leaf $\mathrm{Mn}$ concentration across HLB status and year (Table 1). The $4 \mathrm{x}$ rate always resulted in the highest leaf Mn concentration. For HLBaffected trees, leaf concentration in $4 \mathrm{x}$ were $700 \%$ and $600 \%$ greater than in $1 \mathrm{x}$ fertilized trees in 2019 and 2020, respectively; non HLB showed a similar increase.

The relationship among Mehlich-3 extractable $\mathrm{Mn}$ and other macro and micro nutrients is of paramount importance when devising fertilization strategies. For HLB-affected trees, soil $\mathrm{Mn}$ correlated positively with $\mathrm{Fe}$ and $\mathrm{Cu}$ and negatively with $\mathrm{B}$ and $\mathrm{Zn}$ correlation (Table 2). The trend for soils from non-HLB containers was the same, except that there was no correlation between $\mathrm{Mn}$ and Fe. Of particular concern is the negative correlation between $\mathrm{Mn}$ and $\mathrm{B}$ of -0.76 in HLB containers and -0.58 in non-HLB containers. Combined with the fact that Mehlich 3 likely overestimates plant-available B, this could mean problems.

Concentration of CLas DNA in leaf tissue. Average concentration of CLas DNA ranged between 20 and 30 in 2019 and 25 and 30 in 2020. There was no significant effect of $\mathrm{Mn}$ application on $\mathrm{Ct}$ values for both 2019 and 2020 (Fig. 4).

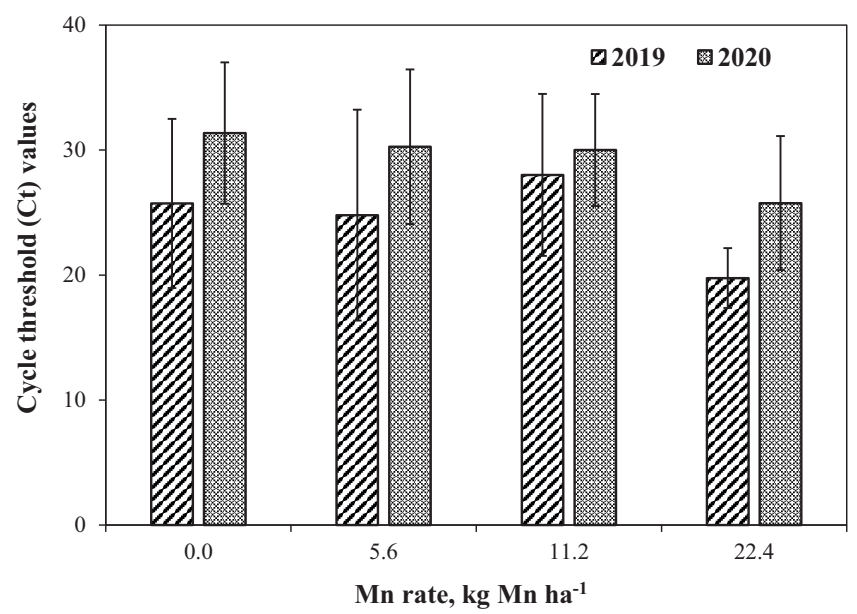

Fig. 4. Concentration of Candidatus Liberibacter asiaticus (CLas) DNA in leaf tissue taken from symptomatic fully expanded Huanglongbing (HLB)-infected leaves for Spring 2019 and 2020 as a function of four Mn application rates on HLB-affected 2-year-old 'Valencia' (Citrus sinensis) in the greenhouse. Rates were 0.0 (Control), 5.6 [Standard recommendation-1x by University of Florida Institute for Food and Agricultural Sciences (UF/IFAS)], 11.2 (2x UF/IFAS rate), and $22.4 \mathrm{~kg} \cdot \mathrm{ha}^{-1}$ Mn (4x UF/IFAS rate). 
Tree dry matter and Mn accumulation. The total dry matter per tree ranged from 324 to $490 \mathrm{~g}$ of which the $2 \mathrm{x}$ treatment had the maximum weight and treatment $4 \mathrm{x}$ had the minimum weight in non-HLB trees (Table 3 ). Non-HLB trees had an overall biomass between $5 \%$ and $13 \%$ greater $(P<0.001)$ than the corresponding fertility level for HLB trees, except for the highest rate, where the non-HLB biomass was smaller than for HLB trees.

For HLB-affected trees, the $2 \mathrm{x}$ rate gave the most dry matter $(P<0.05)$, which was $3 \%$ to $5 \%$ greater dry matter than the control and the $4 \mathrm{x}$ rate (Table 3 ). Aboveground dry matter had at least $30 \%$ more biomass than belowground dry matter among all treatments within HLB-affected trees. Among the aboveground dry matter, trunk showed the most biomass while twigs had the least for both HLB and non-HLB affected trees, but these differences were not significant. For HLB-affected trees, the $2 \mathrm{x}$ rate had $4 \%$ to $8 \%$ more branches than trees treated with $4 \mathrm{x}$ and $0.0 \mathrm{Mn}$, respectively $(P>0.05)$.

Generally, non-HLB trees had the most small roots $(P<0.029)$ relative to HLBaffected trees (Table 3 ). The medium roots (with diameter between 1 and $3 \mathrm{~mm}$ ) had the lowest values of belowground dry matter, while the large roots (root $>3 \mathrm{~mm}$ ) showed the maximum values of the belowground dry matter.

Optimum Mn estimation. For the total dry weight biomass, the peak was achieved with an Mn rate of 10.0 and $10.2 \mathrm{~kg} \cdot \mathrm{ha}^{-1}$ in HLB-affected and non-HLB trees, respectively (Fig. 5). While the above-mentioned $\mathrm{Mn}$ rate gave the maximum response, a lower and upper $95 \%$ confidence interval (CI) at which total dry weight biomass is nearly maximum was calculated to be 9.2 and $10.8 \mathrm{~kg} \cdot \mathrm{ha}^{-1} \mathrm{Mn}$ for HLB-affected trees and 8.9 and $11.5 \mathrm{~kg} \cdot \mathrm{ha}^{-1} \mathrm{Mn}$ for nonHLB trees (Fig. 5). We observed a relatively lower CI for HLB-affected trees than non-HLB trees. This means that there is a greater uncertainty about the prediction of the true values for non-HLB trees as compared with HLB-affected trees. For a nearly maximal response of total dry weight biomass to be achieved, an Mn rate within the given range could be applied. Similarly for trunk diameter, a maximal response was achieved with at an Mn rate of 8.4 and 12.2 $\mathrm{kg} \cdot \mathrm{ha}^{-1} \mathrm{Mn}$ for HLB-affected and nonHLB trees, respectively (Fig. 5). However, the CI observed for both HLB-affected and non-HLB trees are wider. Therefore, the trunk diameter data presents a greater uncertainty as to the precise rate when compared with the total dry weight biomass data (Fig. 5).

\section{Discussion}

Nutrient imbalances may be one of the major consequences of HLB in citrus. This study particularly focused on ways to balance $\mathrm{Mn}$ in young sweet orange trees, for better 

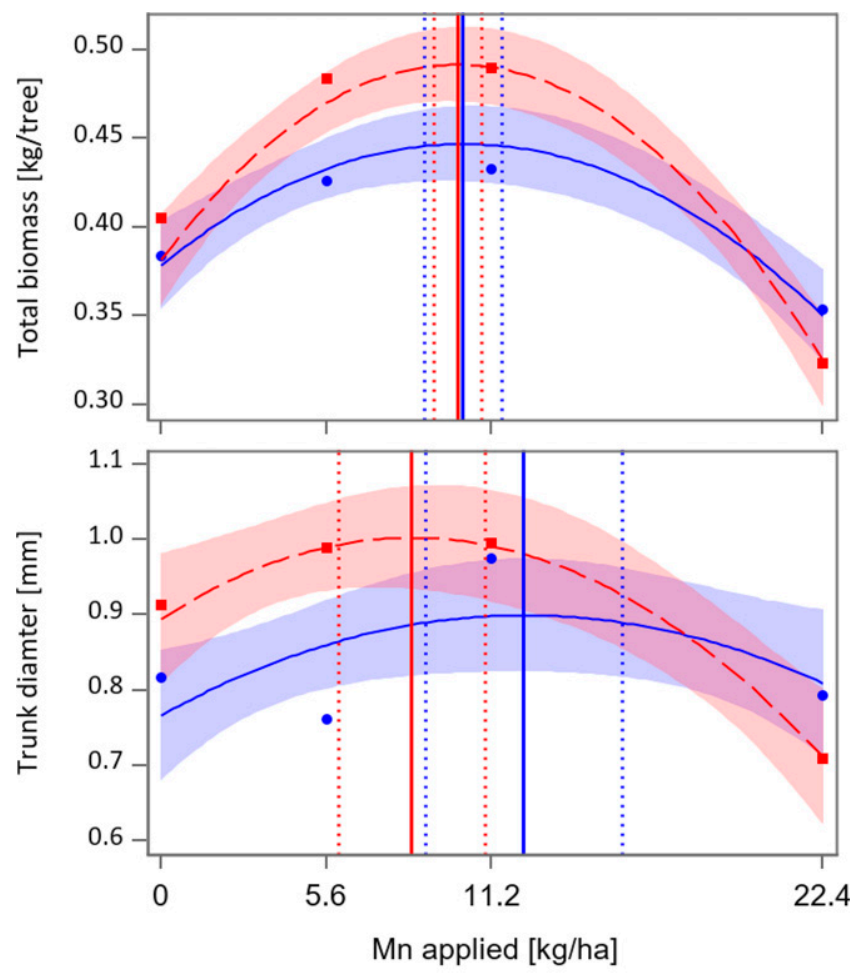

- - -- Non HLB $\longrightarrow$ HLB

Fig. 5. Maximum dry weight biomass ( $\mathrm{kg} / \mathrm{tree})$ and trunk diameter (millimeters) in response to $\mathrm{Mn}$ rates for Huanglongbing (HLB)-affected 2-year-old 'Valencia' [Citrus sinensis (L.) Osbeck] trees. Vertical solid line represents the $\mathrm{Mn}$ rate at which maximal response was achieved, and vertical dotted lines represent the lower and upper 95\% confidence interval. Rates were 0.0 (Control), 5.6 [Standard recommendation-1x by University of Florida Institute for Food and Agricultural Sciences (UF/IFAS)], 11.2 (2x UF/IFAS rate), and $22.4 \mathrm{~kg} \cdot \mathrm{ha}^{-1} \mathrm{Mn}$ (4x UF/IFAS rate). Total sample $(\mathrm{N}=$ 12) for each category.

growth and development. This study showed a linear response of trees to $\mathrm{Mn}$ application (Table 1), suggesting a positive response of soil-applied $\mathrm{Mn}$ in a Candler fine sand. The accumulated $\mathrm{Mn}$ in leaf tissues significantly increased trunk diameter but did not affect tree height (Figs. 2 and 3). For both HLB-affected and non-HLB trees, treatment $2 \mathrm{x}$ had the maximum value for trunk diameter relative to treatment $4 \mathrm{x}$, which suggests that trees treated with $4 \mathrm{x}$ may have experienced stunted growth and some form of toxicity with increasing $\mathrm{Mn}$ rate (Fig. 2). According to Epstein and Bloom (2005), plants that contain at least $50 \mathrm{ug} \cdot \mathrm{g}^{-1}$ $\mathrm{Mn}$ dry weight in leaves are considered to have adequate $\mathrm{Mn}$ for growth and development. But with HLB, this amount could be higher because interveinal chlorosis shows as a symptom of HLB (Morgan et al., 2016), even with trees that receive the standard Mn recommendation. The results from this study (Figs. 1-3) are important in our understanding of $\mathrm{Mn}$ accumulation in tissue and its impact on growth parameters (tree height and trunk diameter) especially, for HLB-affected trees. Our study showed that increasing Mn application increased $\mathrm{Mn}$ accumulation in leaves and large roots for HLB-affected trees. However, for medium and smaller roots applying a rate of $2 \times$ seemed appropriate for HLB-affected trees.
In general, the HLB-affected trees had lower total dry weight for below- and aboveground biomass $(P=0.019)$ as compared with non-HLB trees (Table 3, Fig. 5). In most cases, dry weight biomass tended to increase with an increase in Mn application until 2x, then started to decrease (Table 3, Fig. 5). This may best describe why it is ideal to keep the optimal $\mathrm{Mn}$ rate, as insufficient amounts and overdose may affect dry weight biomass accumulation, even for HLB-affected sweet orange. Zambon et al. (2019) found that higher levels of Mn were good to improve growth and health of bearing and mature HLB-affected trees and for suppression of CLas multiplication (Zambon et al., 2019). This study did not find a significant impact of increasing $\mathrm{Mn}$ fertilizer rate on $\mathrm{Ct}$ values of HLB-affected trees (Fig. 4), although the average $\mathrm{Ct}$ values recorded in Spring 2020 were higher than those of Spring 2019 for all treatments. Our findings suggest that to promote trunk diameter growth and biomass accumulation for young HLB-affected trees, $\mathrm{Mn}$ application should be within an Mn range of 8.9 and $11.5 \mathrm{~kg} \cdot \mathrm{ha}^{-1} \mathrm{Mn}$ (Fig. 5).

Root size distribution in the rhizosphere is determined by the presence of water and nutrients for plants (Gregory, 2006). Table 3 showed that the Mn rate did not impact any of the components of belowground biomass for both HLB-affected and non-HLB trees.
However, non-HLB trees had the most of small (fibrous) roots. These findings are important in our understanding of how $\mathrm{Mn}$ fertilization for HLB-affected trees should be different from non-HLB trees. Our data showed that at similar Mn rates, non-HLB trees accumulated larger total dry weight biomass as compared with HLB-affected trees.

Since trunk diameter, tree height, and biomass accumulation are parameters of growth for the tree crops (Garlobo et al., 2015), it is essential to apply adequate $\mathrm{Mn}$ to maintain the maximum levels of each. For example, among the negative effects of HLB diseases is dieback and loss of roots and canopy size (Graham et al., 2013; Kadyampakeni et al., 2014a), it is imperative to maintain optimal levels of all essential nutrients, especially $\mathrm{Mn}$ to slow down this process. Manganese, as an essential plant nutrient is involved in many plant processes including, redox, activation of varying groups of enzymes, cofactor of enzymes, and proteins required for splitting water in photosystem II (Lambers et al., 2014; Marschner, 1995; Schmidt et al., 2016). Therefore, our findings suggest a Mn rate between 8.9 and $11.5 \mathrm{~kg} \cdot \mathrm{ha}^{-1} \mathrm{Mn}$ (Fig. 5) for young HLB-affected trees in Florida. This rate maintained a sufficient $\mathrm{Mn}$ for the growth and development of young HLB-affected sweet oranges. It may also prevent Mn deficiency in the plant tissue, avoiding the development of necrosis and an increased level of reactive oxygen species (ROS) (Schmidt et al., 2016).

In our study, we established a positive correlation between soil available $\mathrm{Mn}$ with $\mathrm{Fe}$ and $\mathrm{Cu}$, but negative correlation with $\mathrm{B}$ and $\mathrm{Zn}$ (Table 2). These findings suggest that an increase in soil Mn rate does not affect the availability of $\mathrm{Fe}$ and $\mathrm{Cu}$, it, however, may reduce the availability of $\mathrm{B}$ and $\mathrm{Zn}$. This study compares well with the study by Warden and Reisenauer (1991), where soil Mn and $\mathrm{Fe}$ were consistently positively correlated. Our results were also consistent with the study by Yoshiaki and Ando (1968) where they studied the interaction between $\mathrm{Mn}$ and $\mathrm{Zn}$ and found that an increase in $\mathrm{Mn}$ rate reduced the availability of $\mathrm{Zn}$.

The results from our study suggest an optimal Mn range of 8.9 and $11.5 \mathrm{~kg} \cdot \mathrm{ha}^{-1}$ Mn for young 'Valencia' HLB-affected trees in Florida. It is important to mention that we did not find evidence that increasing $\mathrm{Mn}$ rate might suppress CLas bacterial titers 'Valencia' trees, however, increasing the standard recommendation by twice might improve tree growth and development.

\section{Literature Cited}

Ananthakrishnan, G., N. Choudhary, A. Roy, V.G. Sengoda, E. Postnikova, J.S. Hartung, A.L. Stone, V.D. Damsteegt, W.L. Schneider, J.E. Munyaneza, and R.H. Brlansky. 2013. Development of primers and probes for genus and species-specific detection of 'Candidatus Liberibacter species' by real-time PCR. Plant Dis. 97:1235-1243

Blauer, R. 2020. Citrus: World Markets and Trade USDA Foreign Agricultural Service. USDA Foreign Agr. Serv. 13. 
Clarkson, D.T. 1988. The Uptake and Translocation of Manganese by Plant Roots. Manganese in Soils and Plants 101-111, https://doi.org/ 10.1007/978-94-009-2817-6_8.

Epstein, E. and A.J. Bloom. 2005. Mineral nutrition of plants: Principles and perspectives. 2nd ed. Sinauer Associates, Sunderland.

Garlobo, G.R., M.C. Hernandez, W.T. Novel, M.V. Nualles, and M.I. Rosales. 2015. Characterization of the vegetative development and its relationship with fruiting and production of orange trees [Citrus sinensis (L.) Osbeck]. Cult. Trop. 36:56-61, https://doi.org/10.13140/ RG.2.2.24073.85601.

Gherardi, M.J. and Z. Rengel. 2004. The effect of manganese supply on exudation of carboxylates by roots of lucerne (Medicago sativa). Plant Soil 260:271-282, https://doi.org/10.1023/B: PLSO.0000030182.11473.3b.

Gilani, K., S. Naz, F. Aslam, and W. Gurley. 2019. A comparison of zinc, phosphorous and potassium levels in leaves and fruit pulp of healthy and huanglongbing affected citrus cultivars. J. Plant Physiol. Pathol. 07:1-8, https:// doi.org/10.4172/2329-955x.1000192.

Gottwald, T.R., J.H. Graham, M.S. Irey, T.G. McCollum, and B.W. Wood. 2012. Inconsequential effect of nutritional treatments on huanglongbing control, fruit quality, bacterial titer, and disease progress. Crop Prot. 36:73-82, https://doi.org/10.1016/j.cropro.2012.01.004.

Graham, R.D. 1979. Transport of copper and manganese to the xylem exudate of sunflower. Plant Cell Env. 2:139-143.

Graham, J.H., E.G. Johnson, T.R. Gottwald, and M.S. Irey. 2013. Presymptomatic fibrous root decline in citrus trees caused by huanglongbing and potential interaction with Phytophthora spp. Plant Dis. 97:1195-1199, https://doi.org/ 10.1094/PDIS-01-13-0024-RE.

Gregory, P.J. 2006. Roots, rhizosphere and soil: the route to a better understanding of soil science? Eur. J. Soil Sci. 57:2-12, https://doi.org/ 10.1111/j.1365-2389.2005.00778.x.

Hall, D.G. and T.R. Gottwald. 2011. Pest management practices aimed at curtailing citrus huanglongbing disease. Outlooks Pest Manag. 22:189-192, https://doi.org/10.1564/22aug11.

Hamido, S.A., K.T. Morgan, R.C. Ebel, and D.M. Kadyampakeni. 2017. Improved irrigation management of sweet orange with huanglongbing. HortScience 52:916-921, https://doi.org/10.21273/ HORTSCI12013-17.

Hijaz, F., Y. Nehela, and N. Killiny. 2016. Possible role of plant volatiles in tolerance against huanglongbing in citrus. Plant Signal. Behav. 11:1-12, https://doi.org/10.1080/ 15592324.2016.1138193.
Kadyampakeni, D.M., K.T. Morgan, A.W. Schumann, and P. Nkedi-Kizza. 2014a. Effect of irrigation pattern and timing on root density of young citrus trees infected with Huanglongbing disease. HortTechnology 24:209-221, https://doi. org/10.21273/horttech.24.2.209.

Kadyampakeni, D.M., K.T. Morgan, A.W. Schumann, P. Nkedi-Kizza, and K. Mahmoud. 2014b. Ammonium and nitrate distribution in soil using drip and microsprinkler irrigation for citrus production. Soil Sci. Soc. Amer. J. 78:645-654, https://doi.org/10.2136/sssaj2013. 07.0319.

Kadyampakeni, D.M., K.T. Morgan, A.W. Schumann, P. Nkedi-Kizza, and T.A. Obreza. 2014c. water use in drip- and microsprinkler-irrigated citrus trees. Soil Sci. Soc. Amer. J. 78:1351-1361, https://doi.org/10.2136/sssaj2014.02.0054.

Killiny, N. and Y. Nehela. 2017. Metabolomic response to huanglongbing: Role of carboxylic compounds in citrus sinensis response to "Candidatus liberibacter asiaticus" and its vector, diaphorina citri. Mol. Plant Microbe Interact. 30:666-678, https://doi.org/10.1094/MPMI-0517-0106-R.

Kozak, M. and H.P. Piepho. 2018. What's normal anyway? Residual plots are more telling than significance tests when checking ANOVA assumptions. J. Agron. Crop Sci. 204:86-98, https://doi.org/10.1111/jac.12220.

Lambers, H., P.E. Hayes, E. Laliberté, R.S. Oliveira, and B.L. Turner. 2014. Leaf manganese accumulation and phosphorus-acquisition efficiency. Trends Plant Sci. 20:83-90, https:// doi.org/10.1016/j.tplants.2014.10.007.

Marschner, H. 1995. Mineral nutrition of higher plants. 2nd ed. Academic Press, London.

Millaleo, R., M. Reyes-Diaz, A. Ivanov, M. Mora, and M. Alberdi. 2010. Manganese as essential and toxic element for plants: Transport, accumulation and resistance mechanisms. J. Soil Sci. Plant Nutr. 10:470-481, https://doi.org/ 10.4067/S0718-95162010000200008.

Morgan, K.T. and D.M. Kadyampakeni. 2020. Nutrition of Florida citrus trees. 3rd ed. Univ. Florida IFAS Ext. SL253, Gainesville, FL.

Morgan, K.T., R.E. Rouse, and R.C. Ebel. 2016. Foliar applications of essential nutrients on growth and yield of 'Valencia' sweet orange infected with huanglongbing. HortScience 51:1482-1493, https://doi.org/ 10.21273/HORTSCI11026-16.

Nwugo, C.C., Y. Duan, and H. Lin. 2013. Study on citrus response to huanglongbing highlights a down-regulation of defense-related proteins in lemon plants upon "Ca. Liberibacter asiaticus" Infection. PLoS One 8:1-13, https://doi. org/10.1371/journal.pone.0067442.
Pittman, J.K. 2005. Managing the manganese: Molecular mechanisms of manganese transport and homeostasis. New Phytol. 167:733-742, https://doi.org/10.1111/j.1469-8137.2005.01453.x.

Rietra, R.P., M. Heinen, C.O. Dimkpa, and P.S. Bindraban. 2017. Effects of nutrient antagonism and synergism on yield and fertilizer use efficiency. Commun. Soil Sci. Plant Anal. 48:1895-1920, https://doi.org/10.1080/ 00103624.2017 .1407429$.

Rouse, R.E., M. Ozores-Hampton, F.M. Roka, and P. Roberts. 2017. Rehabilitation of Huanglongbing-affected citrus trees using severe pruning and enhanced foliar nutritional treatments. HortScience 52(7):972-978, https://doi. org/10.21273/HORTSCI11105-16.

SAS Institute Inc. 2018. SAS/STAT ${ }^{\circledR} 15.1$ User's Guide. SAS Inst. Inc., Cary, NC.

Schmidt, S.B., P.E. Jensen, and S. Husted. 2016. Manganese deficiency in plants: The impact on photosystem II. Trends Plant Sci. 21:622-632, https://doi.org/10.1016/j.tplants.2016.03.001.

Spann, T.M. and A.W. Schumann. 2009. The role of plant nutrients in disease development with emphasis on citrus and huanglongbing. Proc. Florida State Horicultural Sci. 122:169-171.

Spreen, T.H., J.P. Baldwin, and S.H. Futch. 2014. An economic assessment of the impact of huanglongbing on citrus tree plantings in Florida. HortScience 49:1052-1055.

U.S. Department of Agriculture, National Agricultural Statistics Service (USDA-NASS). 2019. Citrus fruits 2019 summary 35. < https://www. nass.usda.gov/Publications/Todays_Reports/ reports/cfrt0819.pdf $>$.

Vashisth, T. and D. Kadyampakeni. 2020. Diagnosis and management of nutrient constraints in citrus, p. 723-737. In: A.K. Srivastava and C. $\mathrm{Hu}$ (eds.). Fruit crops. Elsevier, Amsterdam, Netherlands, https://doi.org/10.1016/B978-012-818732-6.00049-6.

Warden, B.T. and H.M. Reisenauer. 1991. Manganese-iron interactions in the plant-soil system. J. Plant Nutr. 14:7-30.

Yoshiaki, I. and T. Ando. 1968. Interaction between manganese and zinc in growth of rice plants. Soil Sci. Plant Nutr. 14(5):201-206.

Zambon, F.T., D.M. Kadyampakeni, and J.W. Grosser. 2019. Ground application of overdoses of manganese have a therapeutic effect on sweet orange trees infected with Candidatus liberibacter asiaticus. HortScience 54(6): 1077-1086, https://doi.org/10.21273/HORTSCI 13635-18.

Zekri, M., and T.A. Obreza. 2012. Plant nutrients for citrus trees. Univ. Florida-IFAS Ext. 200:1-5. 